\title{
Effect of Different Rates of Organic Manure (Cow Dung) on the Growth of Solanum Lycopersicum L.
}

\author{
Ekwealor K. U. ${ }^{1}$, Egboka T. P. ${ }^{1}$, Anukwuorji C. A. ${ }^{1,{ }^{*}}$, Obika I. E. ${ }^{2}$ \\ ${ }^{1}$ Department of Botany, Nnamdi Azikiwe University, Nigeria \\ ${ }^{2}$ Department of Zoology, Nnamdi Azikiwe University, Nigeria
}

Received February 27, 2020; Revised April 9, 2020; Accepted April 27, 2020

\begin{abstract}
Copyright $\odot 2020$ by authors, all rights reserved. Authors agree that this article remains permanently open access under
\end{abstract} the terms of the Creative Commons Attribution License 4.0 International License

\begin{abstract}
The application of different rates of organic manure (cow dung) on the growth of Solanum lycopersicum L. grown for six weeks in polyethene bags was carried out in this study. The treatments were done in triplicates which include $30 \mathrm{~kg}$ of soil uniformly mixed with $5 \mathrm{~kg}, 10 \mathrm{~kg}, 15 \mathrm{~kg}$, and $20 \mathrm{~kg}$ of cow dung manure and control without (cow dung) manure. Each treatment was replicated three times. The data collected were analyzed using a one-way analysis of variance and mean separation by Duncan Multiple Range Test (DMRT). Solanum lycopersicum with the rate of $20 \mathrm{~kg} / \mathrm{ha}$ increased the percentage germination $(2.66 \pm 2.8)$, height of plant from $(7.66 \pm 1.040)$ in week 1 to $(63.26 \pm 7.166)$ in week 6 , leaf area from $(2.14 \pm 1.540)$ in week 1 to $(71.04 \pm 7.005)$ in week 6 , stem girth from $(1.60 \pm 0.264)$ in week 1 to $(4.23 \pm 0.251)$ in week 6 and the number of branches from $(3.00 \pm 1.000)$ in week 1 to $(14.33 \pm 4.041)$ in week 6 respectively. The control $(0 \mathrm{~kg} / \mathrm{ha})$ gave the lowest in percentage germination $(0.60 \pm 0.100 \%)$, in height, from $(5.06 \pm 0.702)$ in week 1 to $(14.50 \pm 3.968)$ in week 6 , leaf area from $(0.87 \pm 0.280)$ in week 1 to $(7.18 \pm 4.447)$ in week 6 , in stem girth from $(0.50 \pm 0.100)$ in week 1 to $(2.43 \pm 0.251)$ in week 6 and lowest in number of branches from $(0.00 \pm 0.00)$ in week 1 to $(6.00 \pm 1.000)$ in week 6 respectively. Thus, this study alluded that cow dung can be used to enhance the growth, productivity and yield of tomato in low nutrient soil in the rate of $20 \mathrm{~kg} / \mathrm{ha}$ which showed a significant increase in growth and yield of tomato.
\end{abstract}

Keywords Solanum lycopersicum, Organic Manure, Cow Dung, Growth Rate

\section{Introduction}

Solanum lycopersicum commonly referred to as tomato, belongs to family Solanaceae or nightshade, in the order Solanales and the class Magnoliospida. It is a herbaceous dicotyledonous short-lived perennial plant, growing 1-3m tall with a weakly woody stem that sprawls (Heleys and Pek, 2006), cultivated in tropics and subtropics of the world, and can be cultivated in kitchens, gardens, commercial fields, green house and poly house conditions grown as an annual plant. Tomato was originally native from central, south and southern North America from Mexico to Argentina. Tomatoes can be grown in a variety of locations all over the world (Caputo et al., 2004). Many varieties exist, some varieties have erect stems while others have semi-climbing, weaker stems, and need support for a good yield.

Tomato is the third most consumed vegetable in the world after sweet potato and potato (Sadaf et al., 2012), now grown and consumed in diverse ways around the world with various economic values. It is a good source of vitamin $\mathrm{C}$ and contain high amount of lycopene (Tindall,1983). Furthermore, it is used commercially in the production of tomato paste, puree, juice, ketchup, cocktails and as an excellent face mask that has the ability to loosen the top layer of dead skin and capable of giving glow to the skin when rub on the skin concentrating on the sides with black spots or pimples, medicinally as a natural antiseptic agent due to its nicotinic acids (Adekiya and Agbede, 2009) and as comestible in making of sauce, stew and salad. Cow dung manure is the waste product of bovine animal which has no trace of synthetic chemicals that provides nutrient for plant growth and leads to an increase soil $\mathrm{pH}$, organic carbon, nitrogen, phosphorus, calcium, potassium, and sodium (Binoy et al.,2004). Organic manure has no harmful effect in the environment when decomposed partially or completely by the microbes in the soil, the nutrients are released slowly and last for longer time which ensured a longer residual effect in the soil (Mitchell et al.,2007). Apparently, some of the problems encountered by tomatoes farmers include decreasing soil fertility and 
quantity of compost required for optimum productivity (Nielsen, 2003). Although the efficacy of organic manure in the growth and development of vegetables have been established but there is a dearth of information on the efficacy of Cow dung on the yield of tomato. On this note, it becomes highly imperative to undertake this research with the view of gaining insight into the overall performance of tomato as a result of different rates of cow dung application. The farming system of today totally depend on the use of chemical fertilizers and growth regulators for enhancing crop productivity which has led to several ill effects on the environment though the volume of the output might be influenced. Considering the high economic importance of tomato, the unavailability and unaffordability inorganic fertilizers and the availability of cow dung, hence the need for this study. Thus, the aim of this study is to determine the effects of different rates of cow dung manure and the appropriate manure rates for a maximum growth and possibly yield of Solanum lycopersicum.

\section{Material and Methods}

\section{Experimental Location}

The field study was carried out in the Green house of Botany Department at Nnamdi Azikiwe University, Awka, Nigeria. The total annual rainfall is between $1828 \mathrm{~mm}-2000 \mathrm{~mm}$ per year with average temperature of $27^{\circ} \mathrm{C}$.

\section{Sources of Materials}

Seedlings of Solanum lycopersicum used for this work were obtained from the Agricultural Development Centre, Awka. Organic manure (cow dung) and the polythene bag perforated at the base were obtained from Garki market in Amansea, Awka. The sandy loamy soil was obtained from the Green house in the University environment.

\section{Experimental Design}

The experiment was set in A Completely Randomized Design (CRD). Thirty (30kg) of soil and the different levels of organic manure was measured using a weighing balance. The soil was mixed homogenously with the organic manure with different levels and filled in the polythene bags. The treatments were done in triplicates which include $30 \mathrm{~kg}$ of soil uniformly mixed with $5 \mathrm{~kg}, 10 \mathrm{~kg}, 15 \mathrm{~kg}$, and $20 \mathrm{~kg}$ of cow dung manure and control without (cow dung) manure. Each treatment was replicated three times.

\section{Cultural Practice}

The cultural practices used during this experiment included; weeding which was done weekly and the hand picking method was used and watering was done once a week since rainfall at the period was almost consistent.

\section{Growth Indices measured}

The measurements were obtained on weekly basis. The following parameters were measured: Plant height, Plant girth, Leaf area, Number of leaves, Number of branches.

\section{Statistical Analysis}

The data collected were analyzed using one-way analysis of variance (ANOVA) and mean separation by Duncan Multiple Range Test (DMRT). Test of significant was measured with Least Significant Difference (LSD).

\section{Results}

The influence of the different rates of organic manure (cow dung) on Solanum lycopersicum were shown in tables $1-4$. The organic manure at the rate of $20 \mathrm{~kg} / \mathrm{ha}$ gave the highest percentage germination of Solanum lycopersicum $(2.66 \pm 2.886 \%)$ while the $(0 \mathrm{~kg} / \mathrm{ha})$ gave the lowest percentage germination $(0.60 \pm 0.100)$. There was a significant difference in the percentage germination of Solanum lycopersicum between the different rates of cow dung manure $(\mathrm{c}<0.05)$ (Table 1).

Table 1. Percentage Germination of Solanum lycoperscium

\begin{tabular}{|l|l|}
\hline Treatment $(\mathbf{k g} / \mathbf{h a})$ & Percentage germination \\
\hline 0 & $0.60 \pm 0.10$ \\
\hline 5 & $0.66 \pm 0.49$ \\
\hline 10 & $0.93 \pm 0.11$ \\
\hline 15 & $0.86 \pm 0.15$ \\
\hline 20 & $2.66 \pm 0.80$ \\
\hline LSD & 3 \\
\hline
\end{tabular}

Highest height $(\mathrm{cm})$ of the plant was shown in table 2. It was revealed that at the rate of $20 \mathrm{~kg} / \mathrm{ha}$ the highest height increased from $(7.66 \pm 1.040)$ in week 1 to $(63.26 \pm 7.166)$ in week 6 . The control $(0 \mathrm{~kg} / \mathrm{ha})$ gave the lowest increase in height from $(5.06 \pm 0.702)$ in week 1 to $(14.50 \pm 3.968)$ in week 6 . There was a significant difference in the weekly height of Solanum lycopersicum between the different rates of cow dung manure $(\mathrm{P}<0.05)$ (Table 2$)$. 
Table 2. Influence of different rates of cow dung manure on the height $(\mathrm{cm})$ of Solanum lycoperscium measured weekly with significant difference of $(\mathrm{P}<0.05)$.

\begin{tabular}{|c|c|c|c|c|c|c|}
\hline $\begin{array}{c}\text { Treatments (Cow dung in kg/ 30 } \\
\text { kg of soil) }\end{array}$ & Week 1 & Week 2 & Week 3 & Week 4 & Week 5 & Week 6 \\
\hline 0.00 & $5.06 \pm 0.70$ & $4.66 \pm 1.52$ & $8.16 \pm 2.309$ & $9.43 \pm 2.97$ & $11.50 \pm 3.96$ & $14.50 \pm 3.96$ \\
\hline 5.00 & $5.53 \pm 1.00$ & $10.00 \pm 1.00$ & $14.56 \pm 13.99$ & $23.83 \pm 21.42$ & $28.83 \pm 25.32$ & $31.33 \pm 27.30$ \\
\hline 10.00 & $6.73 \pm 0.25$ & $13.33 \pm 0.28$ & $28.00 \pm 2.17$ & $32.83 \pm 2.75$ & $44.16 \pm 2.51$ & $48.83 \pm 0.98$ \\
\hline 15.00 & $7.26 \pm 1.07$ & $14.50 \pm 3.96$ & $35.00 \pm 9.12$ & $43.66 \pm 11.87$ & $56.66 \pm 9.80$ & $59.40 \pm 9.60$ \\
\hline 20.00 & $7.66 \pm 1.04$ & $17.33 \pm 3.51$ & $40.83 \pm 6.00$ & $49.66 \pm 10.01$ & $58.00 \pm 9.26$ & $63.26 \pm 7.16$ \\
\hline
\end{tabular}

The result shown revealed that the rate of $20 \mathrm{~kg} / \mathrm{ha}$ gave the highest increase of leaf area from $2.14 \pm 1.540$ in week 1 to $71.04 \pm 7.005$ in week 6 . The control gave the lowest increase in leaf area from $0.87 \pm 0.280$ in week 1 to $7.18 \pm 4.447$ in week 6. There was a significant difference in the weekly leaf area $(\mathrm{c}<0.05)$ (Table 3$)$.

Table 3. Influence of the different rate of cow dung on the weekly leaf area $(\mathrm{cm})$ of Solanum lycopersicum

\begin{tabular}{|c|c|c|c|c|c|c|}
\hline $\begin{array}{c}\text { Treatment(Cow dung in } \\
\mathrm{kg} / 30 \mathrm{~kg} \text { of soil) }\end{array}$ & Week 1 & Week 2 & Week 3 & Week 4 & Week 5 & Week 6 \\
\hline 0.00 & $0.87 \pm 0.280$ & $2.01 \pm 0.580$ & $3.76 \pm 2.701$ & $4.39 \pm 2.795$ & $5.83 \pm 3.883$ & $7.18 \pm 4.447$ \\
\hline 5.00 & $2.14 \pm 1.540$ & $7.09 \pm 3.770$ & $21.26 \pm 14.07$ & $23.94 \pm 20.79$ & $27.16 \pm 23.81$ & $30.51 \pm 26.78$ \\
\hline 10.00 & $3.71 \pm 1.044$ & $12.12 \pm 1.950$ & $34.12 \pm 5.521$ & $38.46 \pm 9.664$ & $42.26 \pm 9.382$ & $49.39 \pm 8.565$ \\
\hline 15.00 & $4.85 \pm 1.600$ & $3.56 \pm 1.650$ & $42.68 \pm 3.513$ & $48.13 \pm 6.245$ & $53.50 \pm 4.924$ & $58.06 \pm 4.403$ \\
\hline 20.00 & $9.80 \pm 1.000$ & $20.90 \pm 4.350$ & $44.40 \pm 5.386$ & $54.89 \pm 7.166$ & $61.96 \pm 8.544$ & $71.04 \pm 7.005$ \\
\hline
\end{tabular}

For stem girth the table revealed that $20 \mathrm{~kg} / \mathrm{ha}$ of the treatment gave the highest increase in stem girth from $1.60 \pm 0.264$ in week 1 to $4.23 \pm 0.251$ in week 6 while the control $(0 \mathrm{~kg} / \mathrm{ha})$ gave the lowest increase in stem girth from $0.50 \pm 0.100$ in week 1 to $2.43 \pm 0.251$ in week 6 (Table 4).

Table 4. Influence of the different rate of cow dung on the weekly stem girth $(\mathrm{cm})$ of Solanum lycopersicum

\begin{tabular}{|c|c|c|c|c|c|c|}
\hline $\begin{array}{c}\text { Treatments (Cow dung } \\
\text { in kg/ 30 kg of soil) }\end{array}$ & Week 1 & Week 2 & Week 3 & Week 4 & Week 5 & Week 6 \\
\hline 0.00 & $0.50 \pm 0.100$ & $0.86 \pm 0.152$ & $3.26 \pm 0.378$ & $1.66 \pm 1.078$ & $2.03 \pm 0.450$ & $2.43 \pm 0.404$ \\
\hline 5.00 & $0.63 \pm 0.152$ & $1.00 \pm 0.100$ & $5.40 \pm 5.716$ & $1.76 \pm 1.530$ & $1.93 \pm 1.674$ & $2.16 \pm 1.892$ \\
\hline 10.00 & $1.10 \pm 0.264$ & $1.56 \pm 0.208$ & $0.86 \pm 0.152$ & $2.90 \pm 0.100$ & $3.43 \pm 0.737$ & $3.56 \pm 0.288$ \\
\hline 15.00 & $1.20 \pm 0.300$ & $1.60 \pm 0.300$ & $2.00 \pm 0.866$ & $3.26 \pm 0.776$ & $3.43 \pm 0.776$ & $3.73 \pm 0.737$ \\
\hline 20.00 & $1.60 \pm 0.264$ & $1.76 \pm 0.585$ & $2.63 \pm 0.152$ & $3.70 \pm 0.173$ & $4.00 \pm 0.200$ & $4.23 \pm 0.251$ \\
\hline
\end{tabular}

The different rate of cow dung on the weekly number of branches shows that the rate of $20 \mathrm{~kg} / \mathrm{ha}$ gave the highest number of branches from $3.00 \pm 1.000$ in week 1 to $14.33 \pm 4.041$ in week 6 , while the control at the rate of $0 \mathrm{~kg} / \mathrm{ha}$ gave the lowest number of branches from $0.00 \pm 0.00$ in week 1 to $6.00 \pm 1.000$ in week 6 (Table 5).

Table 5. Influence of different rate of cow dung on the weekly number of branches of Solanum lycopersicum

\begin{tabular}{|c|c|c|c|c|c|c|}
\hline $\begin{array}{c}\text { Treatments (Cow dung in } \\
\mathrm{kg} / 30 \mathrm{~kg} \text { of soil) }\end{array}$ & Week 1 & Week 2 & Week 3 & Week 4 & Week 5 & Week 6 \\
\hline 0.00 & $0.00 \pm 0.00$ & $1.33 \pm 1.154$ & $3.33 \pm 0.577$ & $3.66 \pm 0.577$ & $5.00 \pm 1.000$ & $6.00 \pm 1.000$ \\
\hline 5.00 & $1.33 \pm 1.547$ & $3.33 \pm 1.154$ & $4.00 \pm 1.000$ & $4.33 \pm 3.785$ & $5.00 \pm 4.358$ & $5.33 \pm 4.618$ \\
\hline 10.00 & $2.33 \pm 0.577$ & $4.33 \pm 1.154$ & $5.66 \pm 0.577$ & $6.33 \pm 0.577$ & $8.66 \pm 0.577$ & $9.00 \pm 0.000$ \\
\hline 15.00 & $2.33 \pm 0.577$ & $4.00 \pm 0.100$ & $5.66 \pm 1.527$ & $6.66 \pm 1.572$ & $8.33 \pm 0.577$ & $9.33 \pm 0.577$ \\
\hline 20.00 & $3.00 \pm 1.000$ & $4.66 \pm 0.577$ & $7.00 \pm 2.645$ & $9.66 \pm 2.889$ & $12.66 \pm 2.516$ & $14.33 \pm 4.041$ \\
\hline
\end{tabular}




\section{Discussion}

All the rates of manure application in this study appear sub-optimal relative to recommendation by some authors. Influence of different rates of cow dung manure on the growth of tomato revealed that the percentage germination increased with the cow dung manure application of $20 \mathrm{~kg}$ of Cow dung $/ 30 \mathrm{~kg}$ of soil, giving the highest percentage germination. This indicated that the higher rate of cow dung increased the overall parameters for optimum growth; this is in tandem with the report of Adedrian et al., (2003). The growth of tomato checked by height, stem girth, leaf area and number of branches increased with the rate of cow dung manure of $20 \mathrm{~kg}$ of cow dung $/ 30 \mathrm{~kg}$ of soil, giving the highest growth. Thus, an increase in the application of organic manure helps the soil to release these nutrients in large quantities for plants absorption (Smith and Ayenigbara, 2001).

The improvements in soil parameters lead to significant increase in growth and yield of tomato (Adedrian et al., 2003, Anukworji et al. 2012). Aside from improving macronutrient availability, higher rate of organic manure reduces soil bulk density and enhances its moisture content (Ewulo et al., 2008). The increases in height and stem girth are necessary for competition and survival (Akanda et al., 2010). The higher number of branches and leave also shows that it will support photosynthesis activity and high yield.

\section{Conclusions}

This study has shown that cow dung manure can be used to increase and enhance the growth, productivity and yield of tomato in low nutrient soil and can also be used to increase the organic matter and nutrient in low nutrient soil. The study also shows that cow dung in the rate of $20 \mathrm{~kg} / \mathrm{ha}$ showed a significant increase in the growth and yield of tomato. Therefore, cow dung manure in the rate of $20 \mathrm{~kg} / \mathrm{ha}$ should be recommended to farmers for an increase in the growth, productivity and yield of Solanum lycopersicum.

\section{REFERENCES}

[1] Adedrian J.A., Beats N. D., Mnkeni P. N. S., Kiekens L., Muyima N. Y. O. and Thys A. (2003). Organic waste materials for soil fertility improvement in the Border Region of the Eastern Cape, South Africa. Biological Agriculture and Horticulture $20: 283-300$.

[2] Adekiya A. and Agbede T. (2009). Growth and yield of tomato as influence by poultry manure and NPK fertilizer". Emirates Journal of Food and Agriculture 21:10-20.

[3] Akanda M. O. and Adediran J. A. (2004). Effect of terralyt plus fertilizer on growth nutrients uptake and dry matter yield of two vegetable crops. Moor Journal of Agriculture,
5:12-107.

[4] Anukworji C.A., Ramesh R. Putheti and Okigbo, R.N (2012). Isolation of fungi causing rot of cocoyam (Colocasia esculenta (L) Schott) and control with plant extracts. Global Advanced Research Journal of Agricultural Sciences. 1 (2): 033-047.

[5] Binoy G., Charanjit K., Khurdiya D. S. and Hapoor H. C. (2004). Antioxidants in tomato as a function of genotype. Food Chemistry, 84:45-51.

[6] Caputo M., Sommella M. G., Graziani G., Giordano I., Fogliano V. Porta R. and Mariniello L. (2004). Antioxidant profiles of corbara small tomatoes during ripening and effects of aqueous extracts on j-774 cell antioxidant enzymes". Journal of Food Biochemistry 28 :1-20.

[7] Cvetkovic D. and Markovic D. (2008). UV-induced changes in antioxidant capacities of selected carotenoids toward lecithin in aqueous solution. Radiation Physics and Chemistry 77:34-41.

[8] Ewulo B. S.,Ojeniyi S. O. and Akanni D. A. (2008). Effect of poultry manure on selected soil physical and chemical properties, growth yield and nutrient status of tomato. African Journal of Agricultural Research 3 (3):612-616.

[9] Helyes L. and Pek Z. (2006). Tomato fruit quality and content depend on stage of maturity. HortScience 41 (6):1400-1401.

[10] Javaria S., Khan M. Q., Rahman H. U. and Bakhsh I. (2012). Response of tomato (Lycopersicon esculentum L.) yield and post-harvest life to potash levels. Sarhad Journal of Agriculture. 28(2):227-235

[11] Mitchell A. (2007). "Ten-year comparison of the influence of organic and conventional crop management practices on the content of flavonoids in tomatoes'. Journal of Agriculture and Food Chemistry 55(15): 6154-6159.

[12] Nielsen S. (2003). Food Analysis (Third Edition). Kluwer Academia, New York. Pp1-22.

[13] Tindall H.D. (1983). Vegetables in the tropics. Macmillan Education limited, Hampshire Pp 533.

[14] Sadaf, J. Q., Khan, M., Habib, U. R. and Imam, B. (2012). Response of tomato yield and post harvest life to potash levels. Sarhad J. Agric. 28 (2): 227-235

[15] Smith M. and Ayenigbara E. (2001). comparative growth and nutrient composition of Indian Spinach in an enriched humid tropical environment." African Crop Science Conference Proceedings, 5:1007-1013 